\title{
Electrical resistivity tomography (ERT) of pit-and-mound microrelief, Mt Rogowa Kopa case study, the Stolowe Mountains, SW Poland
}

\author{
Łukasz Pawlik', Marek Kasprzak² \\ ${ }^{1}$ Institute of Geography, Pedagogical University of Cracow, Kraków, Poland; lpawlik@up.krakow.pl \\ ${ }^{2}$ Institute of Geography and Regional Development, University of Wrocław, Poland
}

\begin{abstract}
This article presents results of geophysical analyses based on electrical imaging of slope mantles with pit-and-mound microtopography developed on the Rogowa Kopa hillslope in the Stołowe Mountains, SW Poland. The use of two dimensional electrical resistivity tomography (2D ERT) to non-invasive analyses of the hillslope microrelief allowed completing previous results of geomorphological and soil studies. The tomograms (inversion results) acquired across individual forms of treethrow pits and mounds can be interpreted according to regolith thickness and its wetness, but also smaller features such as relict and fresh tree root systems detected in the mounds. These features were compared to a general picture of geoelectrical resistivity measured in the main cross-section of the analyzed hillslope. The differences in slope cover characteristics observed on the tomograms confirm important role of the tree uprooting process in formation of some basic features of the regolith and soils, including their uneven redistribution across the hillslope.
\end{abstract}

Key words: 2D electrical resistivity tomography (ERT), pit-and-mound microtopography, tree uprooting, Stołowe Mountains, Sudety

\section{Introduction}

Geophysical methods effectively support geomorphological research (e.g. Migoń et al. 2010, Pánek et al. 2011). However, so far in the Sudety Mts. they have been applied rather rarely. In the region except the studies of deep geological structures, carried out for geological survey purposes, geophysical analyses in the form of electrical resistivity measurements were used for instance to recognise karst caverns in the Śnieżnik Massif and Krowiarki mountain range (Bieroński 1978). In recent years the electrical resistivity tomography (ERT) has started to be used in geomorphological studies more frequently. This method, which combines advantages of electrical resistivity sounding and traversing, together with modern software used in post-processing of measuring data has been applied to detect for instance:

- various forms developed due to the growth of ground ice within pit-bogs of the Karkonosze summit area (Dohnal et al. 1999),

- landslide hillslopes in the Kamienne Mts. (Migoń et al. 2010),

- complexity of the Sudetic Marginal Fault zone (Štěpančíková et al. 2011),

- characteristics of alluvial sediments (Kasprzak, Traczyk 2013).
However, the ERT method has not been used to characterize surficial forms of microrelief within forested hillslopes. Its application is very useful especially in the areas under strict nature conservation, where traditional methods of soil analyses that require making of soil pits and soil samples collection, are normally restricted by many regulations, and therefore practically difficult to achieve.

The aim of this study was to obtain new information about a pit-and-mound microtopography that developed on the forested hillslopes of Mt Rogowa Kopa (RK) in the Stołowe Mountains by using of the ERT method. Our results of the measurements and analyses complement the previous results of studies of morphological effects of the tree uprooting process in this area (Migon et al. 2011, Pawlik 2012, Pawlik et al. 2013a, b). So far, geophysical researches of similar microrelief were based on the application of ground penetrating radar (GPR), and focused mainly on biomechanical functions of tree roots (Roering et al. 2010). In this respect, the results bring new data and add to the discussion about processes and forms caused by biogenic agents (here predominantly trees), in terms of bioturbations of soils and biomechanical weathering of bedrock (see e.g., Phillips et al. 2008, Gabet, Mudd 2010). 


\section{Subject of the study}

Tree uprooting is a biogeomorphological process that has been under considerable research at least since 1950s (e.g. Denny, Goodlett, 1956). However, its main and most important consequences were underlined in the early pedologic reports, and focused on forest soil properties (Shaler, 1891; Lutz, 1940).

Treethrow pits and mounds are formed when tree is toppled and its root system, together with soil material attached to it, is uplifted and deposited on a slope surface (called windthrows - if caused by wind; wiatrowały, powały in Polish; Gerlach 1960, Brzozowski 1966, Kotarba 1970, Klimaszewski 1981, Faliński 1986, Parzóch 2001, Pawlik 2009, Rojan 2010). During their formation soil material from the root plates of fallen trees is a subject of degradation due to water erosion, rainsplash, gravitational processes, etc. Simultaneously, the tree trunk slowly decomposes. The process of decomposition can take ca. 60 years in case of beech (F. sylvatica) ( ̌́amonil et al. 2009), or even up to 110 year in case of spruce (P. abies) (Zielonka, 2006; Bujoczek 2012). Treethrow mound is normally formed in a place previously occupied by the root plate, whereas treethrow pit occupies a rooting zone of the uprooted tree. However, many additional configurations are possible as it was illustrated for instance by Langohr (1993). When pit-and-mound assemblages cover a larger surface they form so called pit-and-mound microtopography/microrelief (e.g. Denny, Goodlett 1956). The microrelief is the most obvious example of surficial manifestation of soil and regolith bioturbations caused by root system of a fallen tree within forested hillslope domain, and it is directly attributed to the tree uprooting process (e.g., Šamonil et al. 2010, Pawlik 2013, and references cited therein). Trees are uprooted mainly due to the impact of strong winds of various types which in temperate forests happen for instance during windstorms - extra-tropical cyclones reaching hurricane velocity (e.g. Mitchell 2012). For example, in the Sudety Mts. such phenomena took place in January 2007 (the Kyrill windstorm), in January 2008 (the Paula windstorm) or in March 2008 (the Emma windstorm). Such "clustering of events" frequently takes place over Europe and has serious effects on many forested lands (Everham, Brokaw 1996).

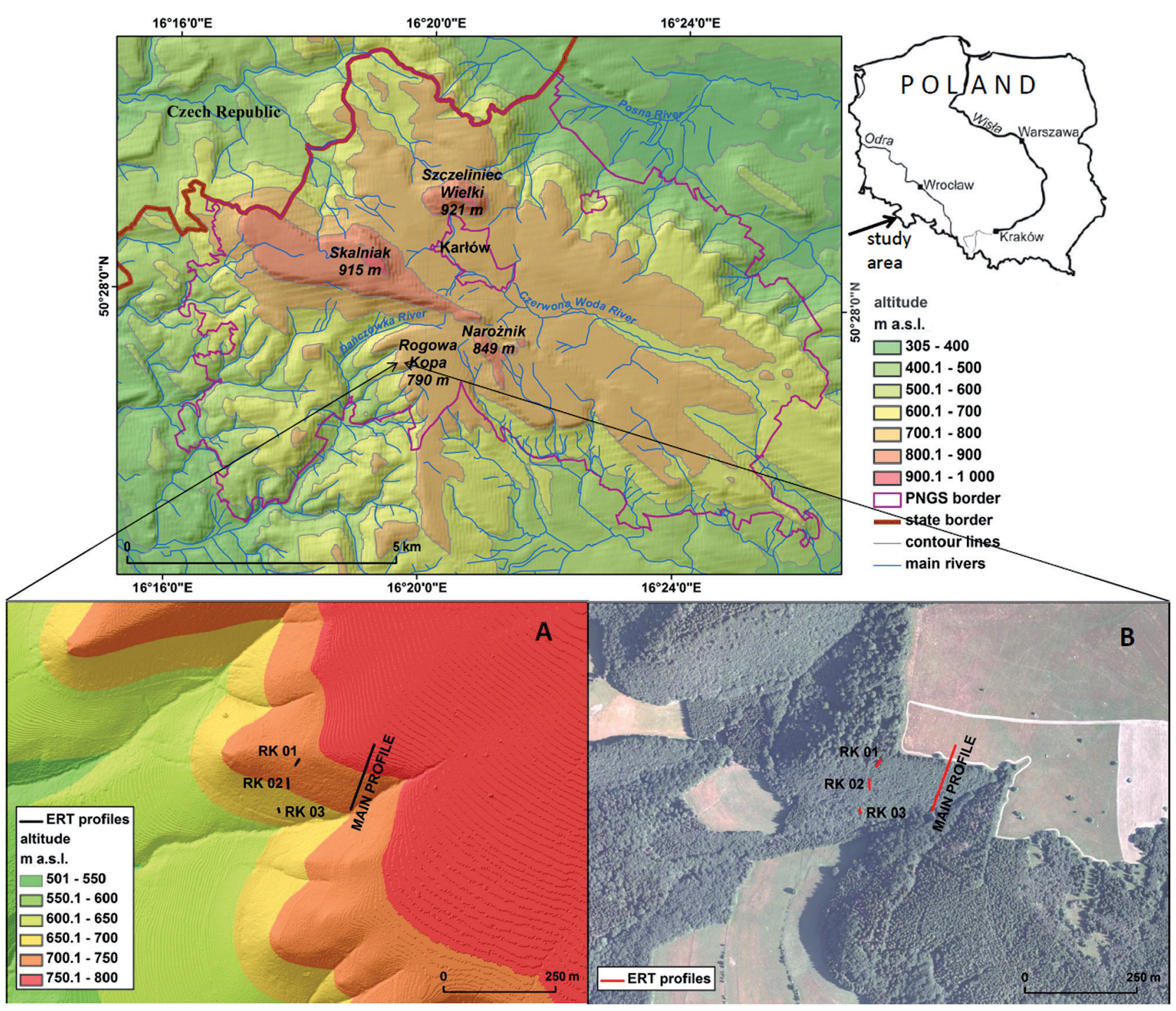

Fig. 1. Study area with places of the ERT sounding marked (A - hypsometry; B - land cover). PNGS - Stołowe Mountains National Park 


\section{Study area}

The analyses were carried out on the southern slopes of Mt RK (790 m a.s.1.) in the Stołowe Mts. (Fig. 1). This area has been chosen due to its very well developed pit-andmound microrelief which is rather uncommon in managed forests. Such type of forest dominates in the Sudety Mts. and for this reason the study site represents a unique locality. The area is under strict environmental protection within the Stołowe Mountains National Park. Mt RK consists of two clearly contrasting relief components:

- a flat deforested mountain top with residual sandstone blocks (Sawanna Łężycka),

- steep (up to $35^{\circ}$ of slope inclination) forested hillslopes (Parzóch, Migoń 2015).

The hillslopes are incised by the $1^{\text {st }}$ order streams that are tributaries of the Dańczówka River. This part of the Stołowe Mts. is built of calcareous mudstones of the Cretaceous age (Turon), with fine-grained rocks, so called "planar marls" (Rotnicka 1996), which belong to the upper heterolithic series (Wojewoda et al. 2011). Geomorphologically this part of the Stołowe Mts. belongs to the $2^{\text {nd }}$ morphostructural level (700-795 $\mathrm{m}$ a.s.1.), the most extensive within the entire massif (Pulinowa 1989, Migon 2008). A blanket of the soil-weathering covers developed there on a bedrock built of marls and mudstones. Haplic Cambisols (eutric) dominates on such substrate; 50-100 $\mathrm{cm}$ deep, with a texture of silt loam and loam, in 0-25 and $25-50 \mathrm{~cm}$ horizon respectively (Kabała et al. 2002, 2008, 2011).

Within the research polygon (2.3 ha in size), 82 pairs of the treethrow mounds and pits were mapped with average surface of $7 \mathrm{~m}^{2}$ in case of mounds and $6.5 \mathrm{~m}^{2}$ for pits. All the mapped forms cover $4.7 \%$ of the research site (Pawlik et al. 2013a). The forest type was classified as fertile Sudetic beech stand (Dentario enneophyllidis-Fagetum typicum), with the average tree age reaching 80 years (Opis taksacyjny... 2009), but on the neighbouring hillslope single beech trees are even 180 years (Migoń et al. 2011). In the studied forest stand beech trees (F. sylvatica) constitute $60 \%$ and maple $40 \%$ of its species composition, with occasional single spruces (P. abies) and birches (Betula). In many cases trees bear traces of bending at their bases, which was interpreted as an effect of soil creep (Migoń et al. 2011; Pawlik et al. 2013a).

\section{Research methods and scope of the study}

Two dimensional electrical resistivity tomography was conducted using ARES equipment (GF Instruments, Czech Republic). The measurements were based on detecting of potential differences in many dipole-dipole electrode arrays (two current electrodes $\mathrm{C}_{1}, \mathrm{C}_{2}$ and two potential electrodes $\mathrm{P}_{1}, \mathrm{P}_{2}$ ), that could be recorded in several dozens of electrodes connected by an active multicable and thus forming a sort of profile. Changes in the measuring electrodes were performed automatically. As a result, taking into account a geometric factor dependent on the applied electrode array and the length between electrodes, we obtained information about the apparent resistivity of the ground in many points, that formed several horizons under slope surface. The dipole-dipole array was chosen in order to detect more precisely a resistivity variability in the horizontal distribution as it gives more measuring points. This feature distinguishes it from other possible to apply systems, as for instance Wenner or Schlumberger electrode arrays (Loke 2000, Milsom 2003). According to this procedure we recorded one main and three shorter profiles. Through the main profile we aimed to recognize variability in the shallow ground characteristics across the entire analysed hillslope. The shorter profiles helped to detect regolith and soil features within the treethrow pairs, what required smaller unit electrode intervals. Therefore, the following measurements were conducted:

1. A profile in a cross-section of the entire hillslope ( 165 $\mathrm{m}$ in length, the unit electrode spacing of $3 \mathrm{~m}$ ). This profile includes two hillslope sections characterized by different vegetation cover: 1) between 763 and $740 \mathrm{~m}$ a.s.l., part of the hilltop covered by meadow, 2) between 740 and $710 \mathrm{~m}$ a.s.l., a forested part of the hillslope (Fig. 1);

2. Three smaller sections with clearly distinguished forms of treethrow mounds and pits (from 15.5 to 23.5 $\mathrm{m}$ in length, the unit electrode spacing of $0.5 \mathrm{~m}$ ) (Fig. 1). In this case electrical resistivity was measured at different altitudes in order to obtain more data along the chosen lateral cross-section of the slope: in the upper part (within the forest-meadow boundary), in the middle, and in the lower parts of the hillslope (next to a stream channel, a tributary of the Dańczówka River). The results were post-processed in order to receive their geophysical interpretation (inversion), using RES2DINV software (Geotomo, Malaysia), and then two-dimensional resistivity models (tomograms). During the inversion the programme matches calculated response of the model to a given set of measurement data. The obtained resistivity model has been modified by iteration for reduction of differences between the model response and the measured values (Loke 2013). Its graphical illustration (tomogram) was prepared with the use of logarithmic contour intervals in a colour scale. The data handling was prefaced by removal of points with undoubtedly erroneous values resulted from technical difficulties in the equipment functioning during field measurements, for instance due to a weak contact between electrodes and the ground (Manual for RES2DINV 2013).

\section{Results and discussion}

\section{Main geoelectrical features of bedrock}

The inversion results (tomograms) of the main slope profile of the south-western hillslope of Mt RK show stratigraphic layers of bedrock in monoclinic configuration 


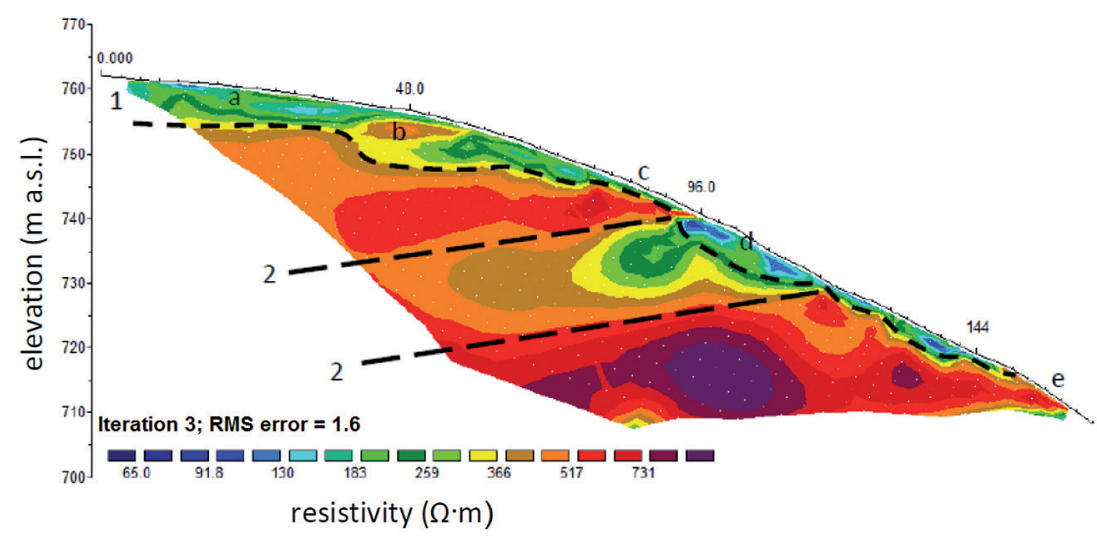

Fig. 2. Inversion results of the ERT measurements along a general hillslope cross-section at Rogowa Kopa (length $165 \mathrm{~m}$, unit electrode spacing 3 m, 3 Iteration, RMS error 1.6)

1 - weathering cover of various thickness dependent on location within the slope and bedrock features; 2 - boundaries between rocks of different geoelectrical characteristics; $\mathrm{a}$ - thicker slope cover near the summit area; b - migrated rock fragment (?); c - abrupt decrease in the weathering cover thickness; $d$ - thicker (watery) part of the slope cover above the middle rock layer; $\mathrm{e}$ - bedrock outcrop above a stream

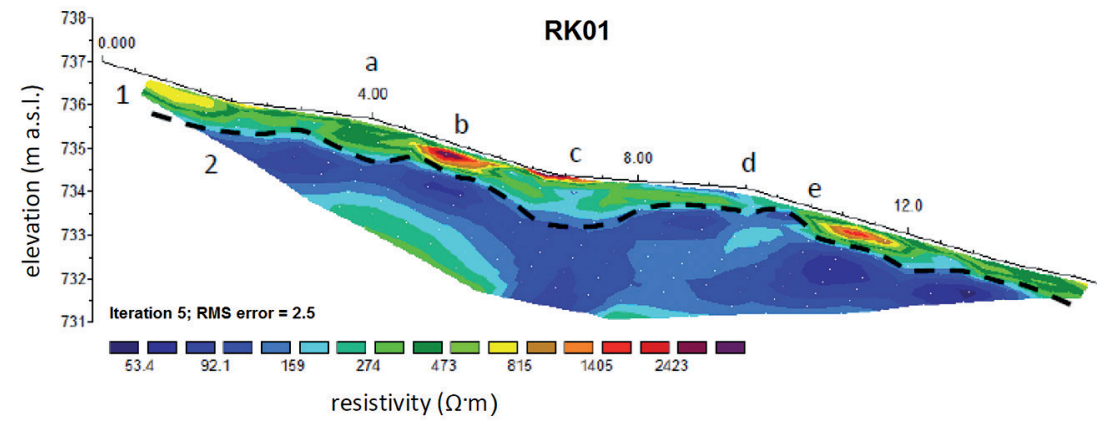

Fig. 3. Inversion results of the ERT measurements at "RK 01" site (length $15.5 \mathrm{~m}$, unit electrode spacing $0.5 \mathrm{~m}, 5$ Iteration, RMS error 2.5)

1 - the upper part of the weathering cover; 2 - deeper bedrock; a - very large treethrow mound and pit; $b$ - trunk of fallen birch and the root system of other tree; $\mathrm{c}$ - treethrow pit; $\mathrm{d}$ - treethrow mound; $\mathrm{e}$ - beech tree root system?

which differentiates geoelectrically (Fig. 2). The bedrock outcrops of various rock types observed here (Fig. 2, c, d, e) imply the thickness of the weathering cover and, as we suppose, the dynamics of gravitational processes on the hillslope, due to the volume of soil-weathering material available for transportation. The differences visible in the thickness of weathering profile depend also on the position within the hillslope, and are strongly related to its convex lateral curvature. The soil-regolith cover is much thicker in the upper section, and thinner in a steeper part of the hillslope where a mudstone outcrop was recorded (Fig. 2, e). The rock fragment (Fig. 2, b) can be interpreted as a residual part of bedrock (a block of mudstone or sandstone?, residuum of the $1^{\text {st }}$ morphostructural level?, almost completely eroded and visible on Mt RK hilltop only as scattered sandstone boulders, see discussion in Parzóch et al. 2009, and Parzóch and Migoń, 2015). Within the slope cross-section thicker and wetter parts are also clearly distinguishable (e.g. section d, Fig. 2).

\section{Detailed examination of the microrelief}

Much shorter but more detailed profiles show variability in geoelectrical resistivity of the upper horizons of the slope covers (Fig. 3, 4 and 5). It can be seen that the treethrow mounds are forms of higher resistivity potential (Fig. 4 and 5) what is a consequence of their lower moisture content. The treethrow pits are above and in close proximity of the parts of the ground that were strongly disturbed, and therefore their geoelectrical features vary significantly. For instance, resistivity measurements in RK02 site show larger rock fragments which had been moved, and/or preserved remnants of tree root systems. Other interpretations of the detected differences in resistivity are less probable in this case, what was previously proved by detailed examination of their soil profiles (Pawlik et al. 2013b). During this study, which was supported by soil analyses and geomorphological research methods, it was shown that RK02 is relatively younger than other forms. For instance, inside one of the mounds a buried tree trunk and relict humus horizon were discovered. In other pit-mound complexes only a buried humus horizon was found (RK03), but no remnants of wood of any type (trunk or roots) (RK01; Fig. 3). When compared with RK01 and RK03, resistivity in RK02 is at its highest scope (Fig. 4 and 6). This part of the slope, with visible thinner soil and regolith cover, can be correlated with the elevation level of 700-720 $\mathrm{m}$ above the 


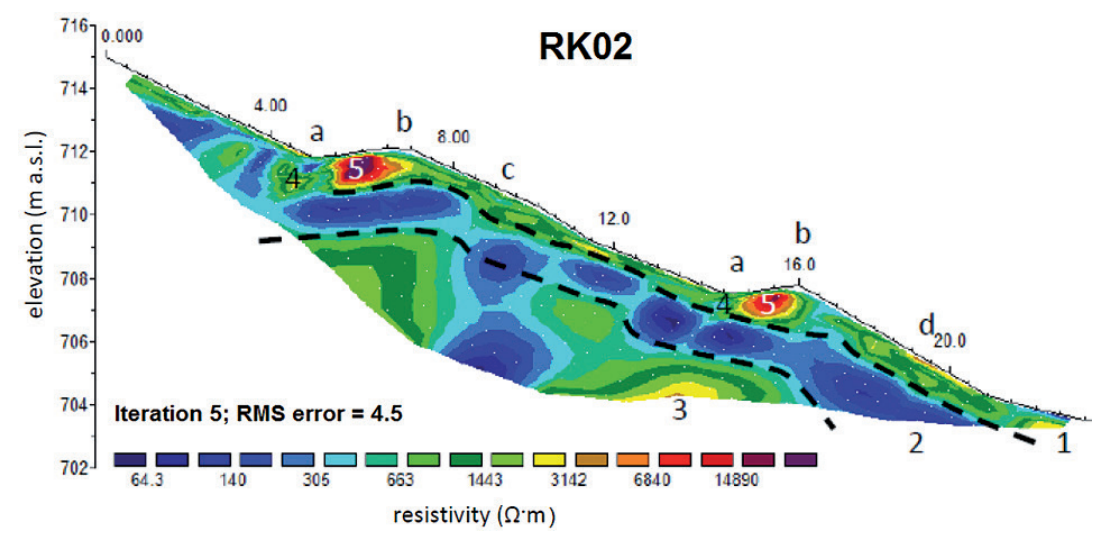

Fig. 4. Inversion results of the ERT measurements at "RK 02" site (length $23.5 \mathrm{~m}$, unit electrode spacing $0.5 \mathrm{~m}, 5$ Iteration, RMS error 4.5)

1 - the upper part of the weathering layer with a higher electrical resistivity; 2 - the lower part of the weathering layer with a lower electrical resistivity; 3 - unweathered bedrock?; 4 - mixed material of different geoelectrical characteristics; 5 - material of relatively high resistivity (dry); a - treethrow pit; $\mathrm{b}$ - treethrow mound; $\mathrm{c}$ - beech tree root system; $\mathrm{d}$ - tree root systems (maple, beech)

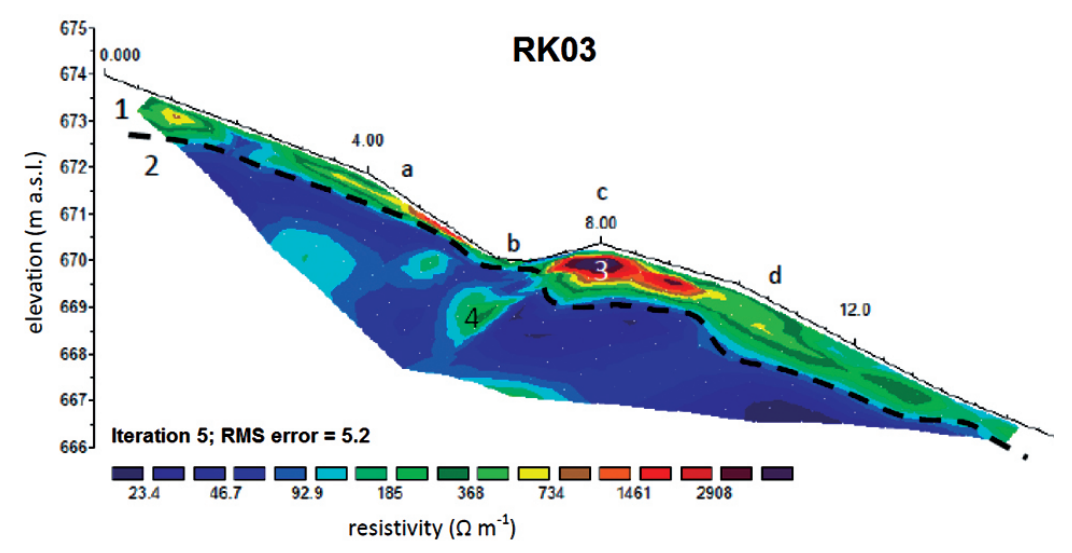

Fig. 5. Inversion results of the ERT measurements at "RK 03" site (length $15.5 \mathrm{~m}$, unit electrode spacing $0.5 \mathrm{~m}, 5$ Iteration, RMS error 5.2)

1 - the upper part of the weathering layer with a higher electrical resistivity; 2 - the lower part of the weathering profile with a lower electrical resistivity; 3 - material of relatively high resistivity (dry); 4 - material of higher resistivity (rock fragments/root systems remnants); $\mathrm{a}$ - maple root system; $\mathrm{b}$ - treethrow pit; $\mathrm{c}$ - treethrow mound; $\mathrm{d}$ - beech tree root system

sea, as shown on the main profile (Fig. 2). In the case of RK01 (relatively oldest form) differences between the pits and mounds are not so distinctively detectable. Only the spots of higher resistivity at RK01 tomogram (Fig. 3) indicate root zones of living and/or broken trees. We considered this form as fairly homogenized example of pit-mound pair with no traces of past pedoturbations within A or B horizons, which could be directly attributed to tree uprooting.

RK03 pit-mound pair was formed in a place of the highest weathering cover thickness (Fig. 5 and 6). It is in the lower part of the slope, where organo-mineral material derived from the upper part of the research polygon was accumulated. This section of the hillslope is much wetter when compared to other parts of the slope profile, and it is also characterised by the lowest values of electrical resistivity in almost entire cross-section. Such situation is in the largest contrast with RK02 profile (Fig. 6). As a rule, tree root systems are very well visible within all analysed hillslope cross-sections. Additionally, within the lower mound at RK02 site remnants of the tree trunk and root systems were detected. Probably an analogous case is in the top part of the profile where soil pits had not been made, which is suggested by similar values of electrical resistivity in this part of the tomogram.

\section{Final remarks and conclusions}

ERT is a very useful and practical research tool for pitand-mound microtopography analyses, and is also used to study the features of shallow bedrock and soil-weathering mantles. It is especially important in places under strict protection, e.g., nature reserves where preparation of many soil pits is inadvisable. Thanks to the previous geomorphological and soil analyses in the Mt Rogowa Kopa we planned the geophysical research in such manner that it enabled us to verify the tomograms without additional preparation of new soil pits. The electrical resistivity tomograms allowed to make conclusions on the dynamics of surficial morphogenetic processes affecting weathering cover thickness and its redistribution. In this case, the process of tree uprooting (treethrow) caused uneven redis- 

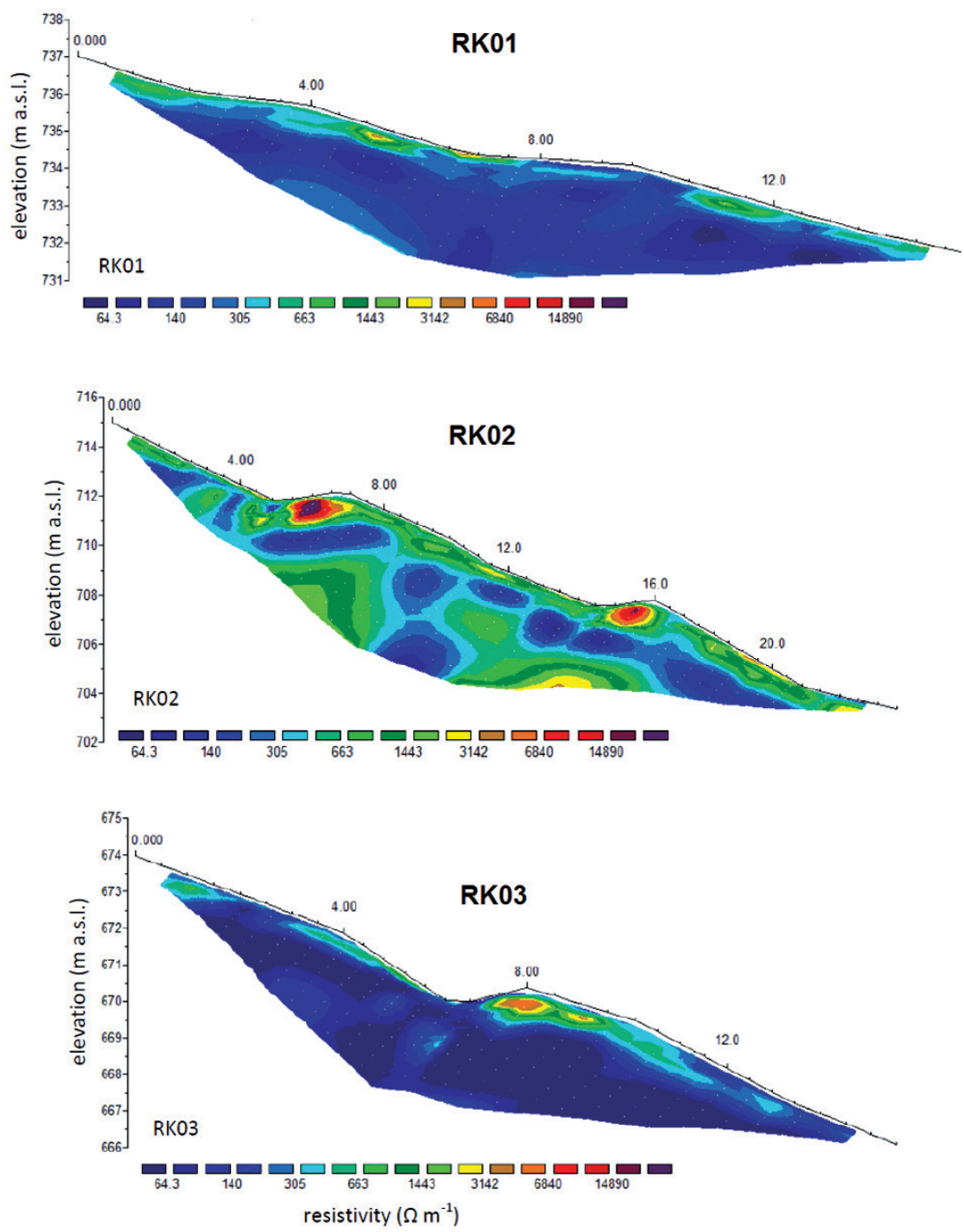

Fig. 6. Inversion results with unified electrical resistivity scale for RK01 (the upper), RK02 (the middle) and RK03 (the lower tomogram)

tribution of soil material and regolith across a slope, and indirectly affected their physical properties e.g. moisture content. The original thickness of the weathering profile, mainly attributed to a character of bedrock and position within a slope, was modified by the process of tree uprooting.

In detail the main conclusions can be formulated as follows:

1. Differentiation of soil-weathering covers at Mt RK has increased due to the influence of tree uprooting, and it was analysed in a smaller scale of pit-mound assemblages through the application of the 2D ERT.

2. The treethrow mounds have higher resistivity due to lower moisture content, presence of tree trunk and root system remnants, and/or larger fragments of bedrock.

3. The treethrow pits have generally lower resistivity due to higher moisture content and accumulated thick layer of organic matter.

4. Due to a higher resistivity of the tree roots than the surrounding soil material, the 2D ERT is an appropriate method of tree root system extension detection.

\section{Acknowledgements}

We thank Ms. Marzena Nowak and Mr. Mateusz Białecki, students of geography, for help during the field studies, and the Stołowe Mountains National Park Directorate for enabling access to their GIS data and permission for the field works within the area of the National Park. The research has been supported by the Ministry of Science and Higher Education grant (NN 306032940) and the Marshall of the Lower Silesia Office Grant Plus, co-financed by the European Social Funds. Comments and suggestions of Prof. Cezary Kabała (Wrocław University of Environmental and Life Sciences, Poland), Łukasz Longosz (M.A., the Edward Stanfords Ltd., London, U.K.) and of two anonymous reviewers on the early draft of this paper are greatly acknowledged.

\section{References}

Bieroński J., 1978. Zastosowanie metody elektrooporowej do badań krasowych na wybranych przykładach z Masywu Śnieżnika Kłodzkiego. Acta Univ. Wratisl., 311, Prace Geograficzne, 24: 97-112. 
Brzozowski S., 1966. Beskidy Zachodnie (450.4). W: J. Kondracki (red.), Sympozjum w sprawie regionalizacji fizyczno-geograficznej Polski i krajów sąsiednich, Przewodnik wycieczki PTG, Warszawa: 17-19.

Bujoczek L., 2012, Dekompozycja obumarłych drzew w ekosystemach leśnych ze szczególnym uwzględnieniem świerka, buka i jodły, Sylwan, 156 (3): 208-217.

Denny Ch.S., Goodlett J.C., 1956. Microrelief resulting from fallen trees, USGS Prof. Publ. 288: 59-68.

Dohnal J., Zdenĕk J., Knĕz J., Vilhelm J., Zima L., 1999. Geofyzikální měření na Labské Louce - příspěvek k poznání palsoidních útvarů. Opera Corcontica, 36: 5-14.

Everham E.M., Brokaw N.V., 1996. Forest damage and recovery from catastrophic wind. The Botanical Review, 62, 2, 113-185.

Faliński J.B., 1986. Vegetation dynamics in temperate lowland primeval forests: ecological studies in Białowieża forest. Dordrecht: W. Junk.

Gabet E.J., Mudd S.M., 2010. Bedrock erosion by root fracture and tree throw: a coupled biogeomorphic model to explore the humped soil production function and the persistence of hillslope soils, Journal of Geophysical Research, 115, F04005, doi:10.1029/2009JF001526.

Gerlach T., 1960. W sprawie genezy kopczyków ziemnych na Hali Długiej w Gorcach. Przegląd Geograficzny, 32, 1-2: 86-93.

Kabała C., Szerszeń L., Wicik B., 2002. Geneza, właściwości i systematyka gleb Parku Narodowego Gór Stołowych. Szczeliniec, 6: 21-94.

Kabała C., Chodak T., Szerszeń L., 2008. Gleby Parku Narodowego Gór Stołowych. W: A. Witkowski, B. M. Pokryszko, W. Ciężkoszwski (red.), Przyroda Parku Narodowego Gór Stołowych, Wydawnictwo PNGS, Kudowa-Zdrój: 70-85.

Kabała C., Chodak T., Bogacz A., Łabaz B., Jezierski P., Gałka B., Kaszubkiewicz J., Glina B., 2011. Przestrzenne zróżnicowanie gleb i siedlisk Parku Narodowego Gór Stołowych. W: T. Chodak, C. Kabała, J. Kaszubkiewicz, P. Migoń, J. Wojewoda (red.), Geoekologiczne Warunki Środowiska Przyrodniczego Parku Narodowego Gór Stołowych, WIND, Wrocław: 141-167.

Kasprzak M., Traczyk A., 2013. LiDAR and 2D Electrical Resistivity Tomography as a suplement of geomorphological investigations in urban areas: a case study from the city of Wrocław (SW Poland). Pure and Applied Geophysics, doi: 10.1007/s00024-013-0693-7.

Klimaszewski M., 1981. Geomorfologia. PWN, Warszawa

Kotarba A., 1970. The morphogenetic role of foehn wind in the Tatra Mts. Studia Geomorphologica Carpatho-Balcanica, 4: 171-188.

Langohr R., 1993. Types of tree windthrow, their impact on the environment and their importance for the understanding of archaeological excavation data. Helinium, 33: 36-49.

Loke M.H. 2000. Electrical imaging syrveys for environmental and engineering studies. A practical guide to 2-D and 3-D surveys. Geotomo, Malaysia.

Loke, M.H., 2013. Tutorial: 2-D and 3-D electrical imaging surveys. Geotomo, Malaysia.

Lutz H.J., 1940. Disturbance of forest soil resulting from the uprooting of trees. Yale University, School of Forestry (Bul. No. 45).

Manual for RES3DINV. Rapid 3-D Resistivity \& IP inversion using the least-squares method (For 3-D surveys using the pole-pole, pole-dipole, dipole-dipole, rectangular, Wenner, Wenner-Schlumberger and non-conventional arrays). On land, aquatic and cross-borehole surveys. Geoelectrical Imaging 2-D \& 3-D. Geotomo Software, 2013.

Migoń, P., 2008. Rzeźba i rozwój geomorfologiczny Gór Stołowych. W: A. Witkowski, B.M. Pokryszko, W. Ciężkowski (red.), Przyroda Parku Narodowego Gór Stołowych, Wydawnictwo Parku Narodowego Gór Stołowych, Kudowa-Zdrój: 49-69.

Migoń P., Pánek T., Malik I., Hrádecký J., Owczarek P., Šilhán K., 2010. Complex landslide terrain in the Kamienne Mountains, Middle Sudetes, SW Poland. Geomorphology, 124: 200-214.

Migoń P., Latocha A., Parzóch K., Kasprzak M., Owczarek P., Witek M., Pawlik Ł., 2011. Współczesny system morfogenetyczny Gór Stołowych. W: T. Chodak, C. Kabała, J. Kaszubkiewicz, P. Migoń, J. Wojewoda (red.), Geoekologiczne Warunki Środowiska Przyrodniczego Parku Narodowego Gór Stołowych, WIND, Wrocław: 1-52.

Milsom J., 2003. Resistivity methods. In: Field Geophysics 3rd Edition. Wiley, Chichester: 97-116.

Mitchell S.J., 2012. Wind as a natural disturbance agent in forests: a synthesis. Forestry, 86: 147-157.
Opis taksacyjny drzewostanów PNGS, 2009. Biuro Urządzania Lasów i Geodezji Leśnej w Brzegu, Archiwum Dyrekcji Parku Narodowego Gór Stołowych, Kudowa-Zdrój.

Parzóch K., 2001. Współczesne procesy geomorfologiczne w Karkonoszach w warunkach antropopresji. Maszynopis pracy doktorskiej, Archiwum Zakładu Geomorfologii IGiRR, Uniwersytet Wrocławski.

Parzóch K., Migoń P., 2015. Deciphering the origin of allochthonous sandstone boulder trains within a mudstone escarpment, Stołowe Mountains, SW Poland. Zeitschrift für Geomorphologie, 59, Suppl. 1: 103-122.

Parzóch K., Migoń P., Latocha A., 2009. Geomorfologiczne efekty długotrwałego cofania stoków w rejonie Sawanny Łężyckiej w Górach Stołowych. Przyroda Sudetów, 12: 87-98.

Pawlik Ł, 2009. Znaczenie saltacji wykrotowej w kształtowaniu rzeźby stoku. Czasopismo Geograficzne, 80, 3: 130-146.

Pawlik Ł., 2012. Przekształcenia powierzchni stokowych w Sudetach w wyniku procesu saltacji wykrotowej. Landform Analysis, 20: 79-94.

Pawlik Ł., 2013. The role of trees in the geomorphic system of forested hillslopes - a review. Earth-Science Reviews, 126: 250-265.

Pawlik Ł., Migoń P., Owczarek P., Kacprzak A., 2013a. Surface processes and interactions with forest vegetation on a steep mudstone slope, Stołowe Mountains, SW Poland. Catena, 109: 203-216.

Pawlik Ł., Kacprzak A., Musielok Ł., Bebak J., 2013b. Distinct form of microrelief on steep slopes of the Rogowa Kopa, Stołowe Mts. - in the light of geomorphological and pedological evidence. W: P. Migon, M. Kasprzak (red.), Sandstone Landscapes. Diversity, Ecology and Conservation. Proceedings of the $3^{\text {rd }}$ International Conference on Sandstone Landscapes, Kudowa-Zdrój (Poland), 25-28 April 2012: 132-138.

Pánek T., Tábořík P., Klimeš J., Komárková V., Hradecký J., Št’astný M., 2011. Deep-seated gravitational slope deformations in the highest parts of the Czech Flysch Carpathians: Evolutionary model based on kinematic analysis, electrical imaging and trenching. Geomorphology, 129: 92-112.

Phillips J.D., Marion D.A., Turkington A.V., 2008. Pedologic and geomorphic impacts of a tornado blowdown event in a mixed pine-hardwood forest. Catena, 75: 278-287.

Pulinowa M.Z., 1989. Rzeźba Gór Stołowych. Prace Naukowe Uniwersytetu Śląskiego w Katowicach, 1008.

Roering J.J., Marshall J., Booth A.M., Mort M., Jin Q., 2010. Evidence for biotic controls on topography and soil production. Earth and Planetary Science Letters, 298: 183-190.

Rojan E., 2010. Rola bardzo silnego wiatru w przekształcaniu rzeźby terenu w piętrze leśnym gór, na przykładzie wiatrowału w słowackich Tatrach Wysokich. Czasopismo Geograficzne, 81, (1-2): 103-123.

Rotnicka J., 1996. Wiek i litologia tzw. margli plenerskich, Szczeliniec. Sympozjum „Środowisko przyrodnicze Parku Narodowego Gór Stołowych", Kudowa Zdrój, 11-13.10.1996, Wydawnictwo Parku Narodowego Gór Stołowych: 21-26.

Shaler N.S., 1891. The origin and nature of soils. In: Powell J.W. (Ed.), USGS $12^{\text {th }}$ Annual report $1890-1891$. Government Printing Office, Washington D.C.: 213-245.

Šamonil P., Antolík L., Svoboda M., Adam D., 2009, Dynamics of windthrow events in a natural fir-beech forest in the Carpathian mountains, Forest Ecology and Management, 257, 1148-1156.

Šamonil P., Král K., Hort L., 2010, The role of tree uprooting in soil formation: A critical literature review. Geoderma, 157, 65-79.

Štěpančíková P., Dohnal J., Pánek T., Łój M., Smolková V., Šilhán K., 2011. The application of electrical resistivity tomography and gravimetric survey as useful tools in an active tectonics study of the Sudetic Marginal Fault (Bohemian Massif, central Europe). Journal of Applied Geophysics, 74: 69-80.

Wojewoda J., Białek D., Bucha M., Głuszyński A., Gotowała R., Krawczewski J., Schutty B., 2011. Geologia Parku Narodowego Gór Stołowych - wybrane zagadnienia. In: T. Chodak, C. Kabała, J. Kaszubkiewicz, P. Migoń, J. Wojewoda (red.), Geoekologiczne Warunki Środowiska Przyrodniczego Parku Narodowego Gór Stołowych, WIND, Wrocław: 53-95.

Zielonka T., 2006. Quantity and decay stages of coarse woody debris in old-growth subalpine spruce stands of the western Carpathians, Poland. Canadian Journal of Forest Research, 36: 2614-2622. 